\title{
The Influence of Electrophoretic Deposition for Fabricating Dye-Sensitized Solar Cell
}

\author{
Jung-Chuan Chou, ${ }^{1,2}$ Shen-Chang Lin, ${ }^{1}$ Yi-Hung Liao, ${ }^{3}$ \\ Jui-En Hu, ${ }^{2}$ Shen-Wei Chuang, ${ }^{2}$ and Chin-Hui Huang ${ }^{2}$ \\ ${ }^{1}$ Department of Electronic Engineering, National Yunlin University of Science and Technology, Douliou, Yunlin 64002, Taiwan \\ ${ }^{2}$ Department of Electronic Engineering and Graduate School of Electronic Engineering, National Yunlin University of \\ Science and Technology, Douliou, Yunlin, Taiwan \\ ${ }^{3}$ Department of Information Management, Trans World University, Yunlin 64063, Taiwan
}

Correspondence should be addressed to Jung-Chuan Chou; choujc@yuntech.edu.tw

Received 9 May 2014; Revised 18 August 2014; Accepted 18 August 2014; Published 28 August 2014

Academic Editor: Teen-Hang Meen

\begin{abstract}
Copyright (C) 2014 Jung-Chuan Chou et al. This is an open access article distributed under the Creative Commons Attribution License, which permits unrestricted use, distribution, and reproduction in any medium, provided the original work is properly cited.

Titanium dioxide $\left(\mathrm{TiO}_{2}\right)$ film was deposited on fluorine-doped tin oxide (FTO) glass substrate by electrophoretic deposition method (EPD). $\mathrm{TiO}_{2}$ films were prepared with different $\mathrm{I}_{2}$ dosages, electric field intensities and deposition time (D.T.), electrophotic deposition times. By different $\mathrm{I}_{2}$ dosages, electric field intensities, deposition time, electrophotic deposition times fabricated $\mathrm{TiO}_{2}$ films and compared photoelectric characteristics of $\mathrm{TiO}_{2}$ films to find optimal parameters which were the highest photovoltaic conversion efficiency. And use electrochemical impedance spectroscopy (EIS) to measure the Nyquist plots under different conditions and analyze the impendence of dye-sensitized solar cells at the internal heterojunction. According to the experimental results, the $\mathrm{I}_{2}$ dosage was $0.025 \mathrm{~g}$ which obtained the optimal characteristic parameters. Thickness of $\mathrm{TiO}_{2}$ film was $10.6 \mu \mathrm{m}$, the open-circuit voltage $\left(V_{\text {oc }}\right)$ was $0.77 \mathrm{~V}$, the short-circuit current density $\left(J_{\text {sc }}\right)$ was $7.20 \mathrm{~mA} / \mathrm{cm}^{2}$, the fill factor (F.F.) was $53.41 \%$, and photovoltaic conversion efficiency $(\eta)$ was $2.96 \%$.
\end{abstract}

\section{Introduction}

Solar energy has been considered as a renewable energy of the next generation since fossil fuel was getting less and less. And dye-sensitized solar cell (DSSC), which was developed by O'Regan and Graetzel in 1991 [1], is highly potential in the solar energy. Titanium dioxide $\left(\mathrm{TiO}_{2}\right)$ had several advantages such as easily tunable bandgap and great absorption dye ability, so it has been a widely used material in many fields, such as photocatalysis, gas sensor, sunscreen, dye-sensitized solar cell, and other applications [2]. Titanium dioxide exists naturally in three nanocrystallines, namely, rutile (tetragonal, $\mathrm{E}_{g}=3.05 \mathrm{eV}$ ), anatase (tetragonal, $\mathrm{E}_{g}=3.23 \mathrm{eV}$ ), and brookite (orthorhombic, $\mathrm{E}_{g}=3.26 \mathrm{eV}$ ).

There are several methods to manufacture titanium dioxide films, such as sputtering [3], hydrothermal method [4], doctor-blade [5], spin coating [6], chemical bath [7], electrophoretic deposition [8], and screen printing [9].
Electrophoretic deposition method has several advantages, such as high deposition rate, simple apparatus, and no binder required. And it also allows us to prepare any kind of conductive substrate shape. In addition, the electrophoretic deposition does not limit to the deposition temperature during processing of depositing $\mathrm{TiO}_{2}$ film [10].

In this study, $\mathrm{TiO}_{2}$ films were prepared by electrophoretic deposition method. Electrophoretic deposition was an attractive technique for the fabrication of films [11, 12]. Electrophoretic deposition was achieved via electrophoretic motion of charged particles in a suspension toward an electrode which depended on the particle charge and formation under the influence of an applied electric field [3].

Recently, for improving the photovoltaic conversion efficiency of dye-sensitized solar cell, the structure of $\mathrm{TiO}_{2}$ has been developed in several forms such as nanosheet [8], nanowire [5], and nanopores [9]. 


\section{Experimental Details}

2.1. Material. Titanium dioxide $\left(\mathrm{TiO}_{2}\right)$ powder (P25) which was purchased from Degussa, Germany, contained $80 \%$ of anatase and $20 \%$ of rutile. The ruthenium-535 (N3) was purchased from UniRegion Bio-Tech, USA. The absolute ethanol was purchased from Katayama Chemical, Japan. The Acetylacetone (AcAc) was purchased from Acros Organics, Belgium. The lithium iodide (LiI) and 4-tert-butylpyridine (TBP) were purchased from Sigma-Aldrich, USA. The iodine $\left(\mathrm{I}_{2}\right)$ was purchased from Riedel-deHaen, USA. The 1-propyl2,3-dimethylimidazolium iodide (DMPII) was purchased from Tokyo Chemical, Japan. And fluorine-doped tin oxide (FTO) glass substrate was purchased from C. P. Solar, Co., Ltd., Taiwan.

2.2. Preparation of $\mathrm{TiO}_{2}$ Suspension and Electrophoretic Deposition. In this experiment, fluorine-doped tin oxide glass substrate was used as the cathode electrode, and platinum $(\mathrm{Pt})$ was used as the anode electrode. The $\mathrm{TiO}_{2}$ suspension consists of $0.25 \mathrm{~g} \mathrm{TiO}_{2}$ powder and $0.02 \mathrm{~g} \mathrm{I}_{2}$ in $25 \mathrm{~mL}$ of Acetylacetone. Before the cathode deposition, the $\mathrm{TiO}_{2}$ suspension was placed in an ultrasonic vibrator to vibrate for 30 minutes. The distance between the cathode and the anode was fixed at $1 \mathrm{~cm}$ and $2 \mathrm{~cm}$. After depositing the $\mathrm{TiO}_{2}$ on FTO glass substrate, $\mathrm{TiO}_{2}$ films were annealed at $450^{\circ} \mathrm{C}$ for 30 minutes. The purpose of annealing is to improve the connection between $\mathrm{TiO}_{2}$ film and substrate. The postannealed electrodes were immediately immersed in an absolute ethanol solution of $3 \times 10^{-4} \mathrm{M} \mathrm{N} 3$ dye for $24 \mathrm{~h}$ at room temperature.

2.3. Fabrication of Dye-Sensitized Solar Cell. The Pt film was fabricated on FTO glass substrate by R.F. sputtering for $90 \mathrm{sec}$ as the counterelectrode. The working electrode and counterelectrode were filled with the liquid electrolyte which consisted of $0.6 \mathrm{M}$ DMPII, 0.5 M LiI, $0.05 \mathrm{M} \mathrm{I}_{2}$, and $0.5 \mathrm{M}$ TBP in $15 \mathrm{~mL}$ MPN. Finally, DSSC was sealed as the sandwich structure of DSSC device. The active area of the solar cell was $0.8 \mathrm{~cm} \times 0.8 \mathrm{~cm}$.

2.4. Measurement. Surface morphology of $\mathrm{TiO}_{2}$ film was measured by scanning electron microscope (SEM). The short-circuit current density $\left(J_{\mathrm{sc}}\right)$, the open-circuit voltage $\left(V_{\mathrm{oc}}\right)$, the fill factor (F.F.), and the photovoltaic conversion efficiency $(\eta)$ of DSSC were measured by Keithley 2400 digital source meter under one sun illumination (AM $1.5 \mathrm{G}$, $100 \mathrm{~mW} / \mathrm{cm}^{2}$ ).

\section{Results and Discussion}

3.1. Electrophoretic Kinetics. According to the Hamaker equation $[16,17]$, the relation between the deposited weight $(w)$ and the electric field intensity $(E)$ is

$$
\text { Mass }=\int_{0}^{t} A C \mu E d t \text {, }
$$

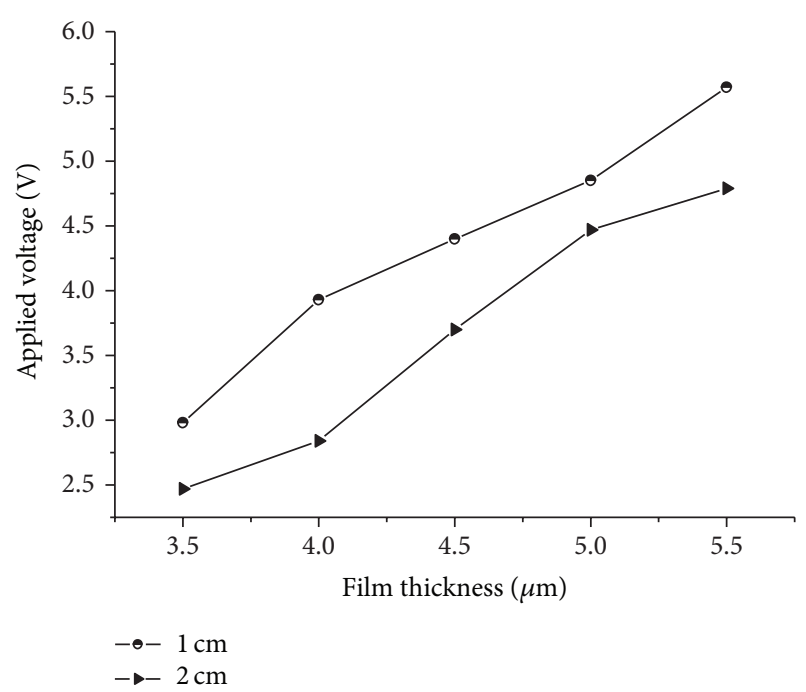

FIGURE 1: The $\mathrm{TiO}_{2}$ films fabricated by different applied voltages and electrode distances.

where $\mu$ is the electrophoretic mobility, $A$ is the surface area of the electrode, $C$ is the concentration of the suspension, and $t$ is the time.

The $\mathrm{TiO}_{2}$ films were fabricated with different voltages. The larger applied voltage was applied, which could increase $\mathrm{TiO}_{2}$ film thickness. The experimental results were as shown in Figure 1. The $\mathrm{TiO}_{2}$ film thickness was a function of increasing applied voltage. Increasing the voltage could provide larger dragging force, so $\mathrm{TiO}_{2}$ nanoparticles could obtain faster deposition rate. And we also increased the distance between two electrodes from $1 \mathrm{~cm}$ to $2 \mathrm{~cm}$; the $\mathrm{TiO}_{2}$ film thicknesses were thinner with increasing distance between two electrodes, which could lead the higher possibility for $\mathrm{TiO}_{2}$ nanoparticles to collide each other that led to the deceleration and decreased deposition rate. In addition, the larger voltage generated faster deposition rate and formed the thicker $\mathrm{TiO}_{2}$ film thickness, but it also led to the bigger crack on $\mathrm{TiO}_{2}$ film, as shown in Figures 2(a)-2(f).

The numbers of crack seemed to depend on deposition electric field intensity. In the microstructure of $\mathrm{TiO}_{2}$ film which deposited at $4.0 \mathrm{~V} / \mathrm{cm}$ for $1 \mathrm{~min}, \mathrm{TiO}_{2}$ particles seemed to be separated, as shown in Figures 2(a) and 2(b), respectively. The microstructure of $\mathrm{TiO}_{2}$ film which deposited at $4.50 \mathrm{~V} / \mathrm{cm}$ for $1 \mathrm{~min}$ became more concentrated, as shown in Figures 2(c) and 2(d), respectively. And the $\mathrm{TiO}_{2}$ film which was prepared at $5.0 \mathrm{~V} / \mathrm{cm}$ has larger crack as shown in Figures 2(e) and 2(f), respectively. The main reason of crack was that the inorganic solvent rapidly was evaporated from the film surface during the drying process. The presence of nanopores on the film could be a great advantage of absorbing dye.

3.2. J-V Characterization of DSSC. There were few factors that could influence $\mathrm{TiO}_{2}$ films in the preparing process, such as (a) the limitation of distance between two electrodes [16], (b) the decreasing of the suspension concentration [18], 


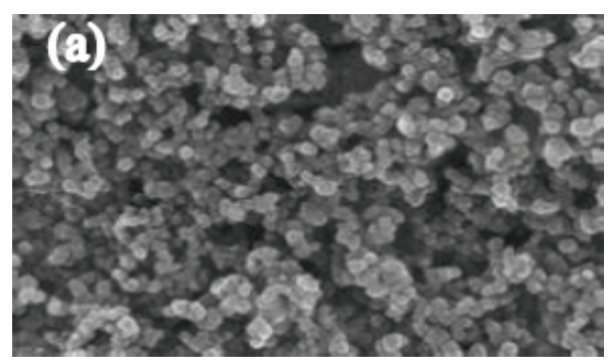

(a)

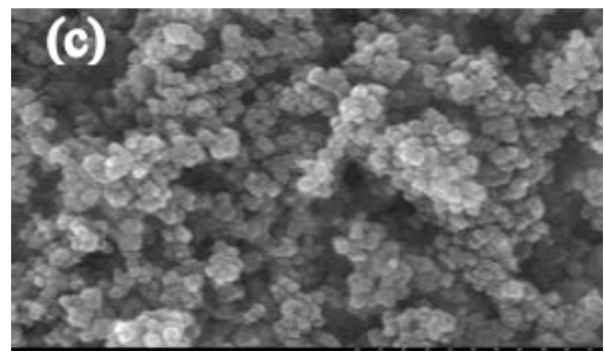

(c)

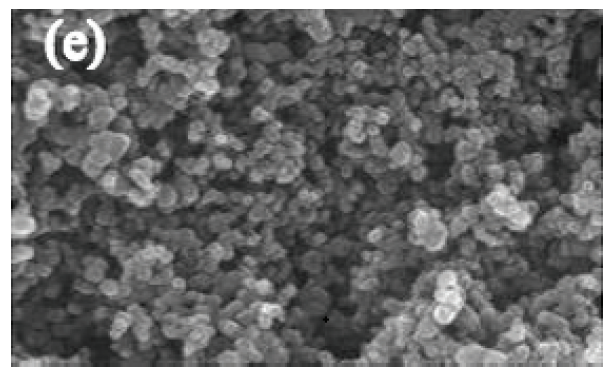

(e)

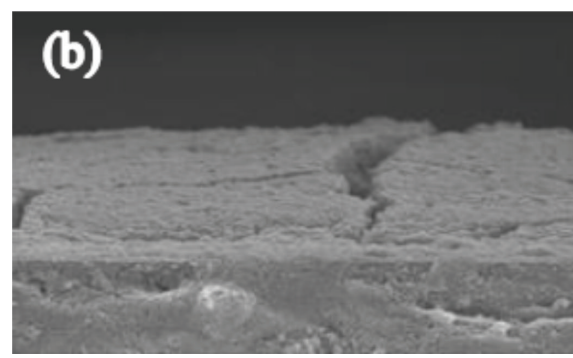

(b)

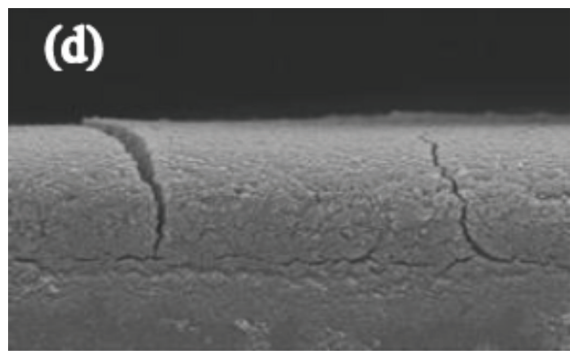

(d)

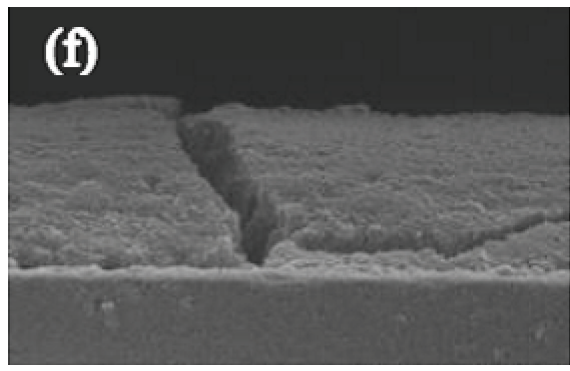

(f)

FIgURE 2: The SEM images of (a) $\mathrm{TiO}_{2}$ film and (b) cross-section deposited at $4.0 \mathrm{~V} / \mathrm{m}$. (c) $\mathrm{TiO}_{2}$ film and (d) cross-section deposited at $4.50 \mathrm{~V} / \mathrm{cm}$, (e) $\mathrm{TiO}_{2}$ film, and (f) cross-section deposited at $5.0 \mathrm{~V} / \mathrm{m}$.

(c) the increasing of deposition resistance [19], and (d) the mobility of $\mathrm{TiO}_{2}$ nanoparticles in the electrophoretic solution [20]. In this experiment, the $\mathrm{TiO}_{2}$ films were fabricated by different deposition time, as shown in Figure 3. We found optimal properties of DSSC in deposition time at $60 \mathrm{~s}$. Moreover, the more $\mathrm{I}_{2}$ dosages at the same deposition time could lead $\mathrm{TiO}_{2}$ nanoparticle (TNP) to carry more electric charges on the $\mathrm{TiO}_{2}$ nanoparticle surface. So the mobility of $\mathrm{TiO}_{2}$ nanoparticle could increase by increasing electric charge at $\mathrm{TiO}_{2}$ nanoparticle surface [19]; the deposition rate and the thickness of $\mathrm{TiO}_{2}$ film were increased by increasing $\mathrm{I}_{2}$ dosages. The experimental results were shown as listed in Table 1.

Figure 4 showed $J-V$ curves of DSSCs, which were prepared with different weights dosages of iodine $\left(I_{2}\right)$. The optimal $\mathrm{I}_{2}$ dosage was $0.025 \mathrm{~g}$ and the thickness was $10.6 \mu \mathrm{m}$. In comparison with $\mathrm{TiO}_{2}$ films which have been prepared with different $\mathrm{I}_{2}$ dosages, both the short-circuit current density and $\mathrm{TiO}_{2}$ film thickness were proportional. The thicker thickness of $\mathrm{TiO}_{2}$ film could increase the amount of

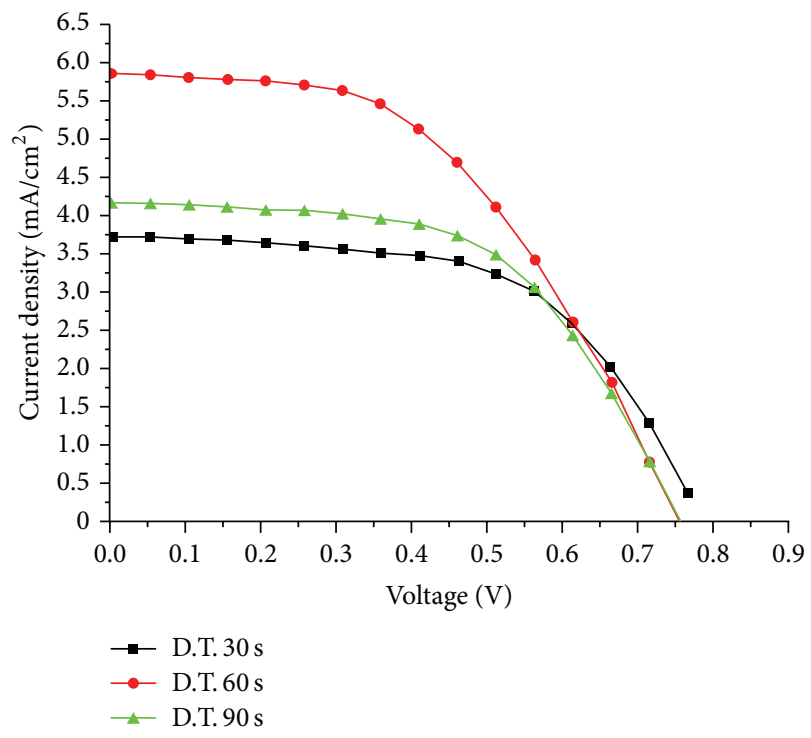

Figure 3: The $\mathrm{TiO}_{2}$ films fabricated by different deposition time. 


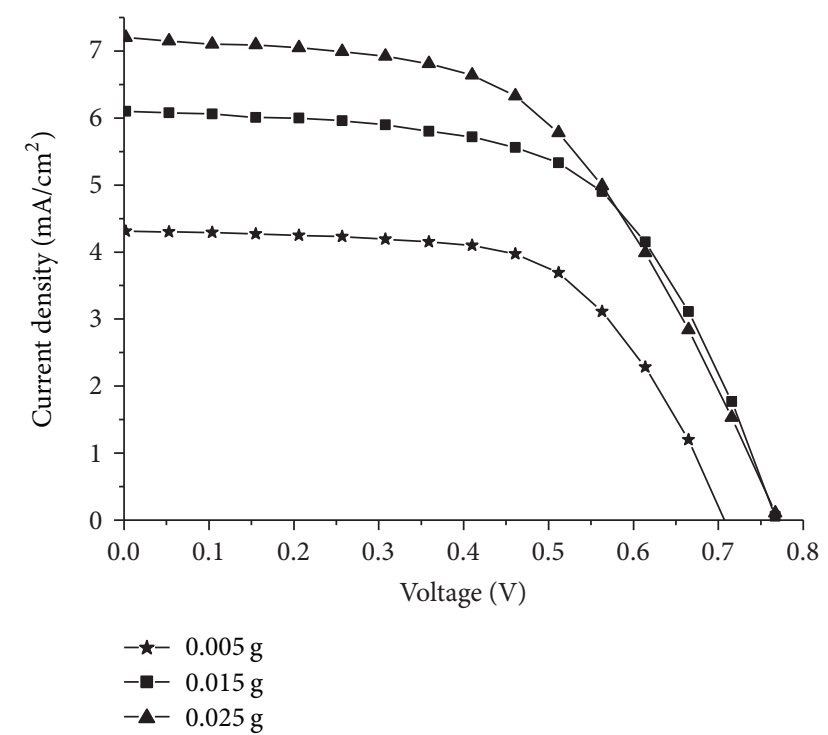

FIgURE 4: The $\mathrm{TiO}_{2}$ films fabricated by different $\mathrm{I}_{2}$ dosages.

TABLE 1: The thicknesses and deposition rates with different $I_{2}$ dosages.

\begin{tabular}{lcc}
\hline $\mathrm{I}_{2}$ dosage $(\mathrm{g})$ & Deposition rate $(\mu \mathrm{m} / \mathrm{sec})$ & Thickness $(\mu \mathrm{m})$ \\
\hline 0.025 & 0.177 & 10.6 \\
0.015 & 0.150 & 9.0 \\
0.005 & 0.125 & 7.5 \\
\hline
\end{tabular}

dye absorption which could generate more photoelectrons. Zhang et al. [21, 22] reported that the thicker thickness of $\mathrm{TiO}_{2}$ film could increase dye desorption and the current density value was dependent on the light absorption which is strongly related to the amount of dye molecules being adsorbed. And, the $\mathrm{TiO}_{2}$ nanoparticles deposited on the conductive substrate were due to an electrostatic attraction force between nanoparticles and FTO glass surface. Nanoparticles were formed by the electrostatic force with the cathode surface, because $\mathrm{TiO}_{2}$ nanoparticles were accumulated with $\mathrm{H}^{+}$ions $[23,24]$.

Table 2 showed the comparison of DSSCs parameters with other references [3, 13-15]; we found that the suspension amount could affect the thickness of $\mathrm{TiO}_{2}$ film; larger suspension amount had longer distance effect, so the $\mathrm{TiO}_{2}$ film thickness could be thinner.

The increasing $\mathrm{TiO}_{2}$ film thickness could increase dye loading of DSSC to generate more photoexcited electrons under the sun irradiation $100 \mathrm{~mW} / \mathrm{cm}^{2}$, so the current density was increased by $18 \%$ (from $6.09 \mathrm{~mA}$ to $7.02 \mathrm{~mA}$ ) [13].

The photovoltaic conversion efficiency could influence not only the thickness of $\mathrm{TiO}_{2}$ layer but also the structure of $\mathrm{TiO}_{2}$ layer. In this study, the structure of photoelectrode was nanopores which were stacked by $\mathrm{TiO}_{2}$ nanoparticles. In the other hand, there were many studies about the structure of $\mathrm{TiO}_{2}$ layer in the photoelectrode which was $\mathrm{TiO}_{2}$ nanotube (TNT). Since the structure of $\mathrm{TiO}_{2}$ nanotube had greater specific surface area than nanoparticles, and

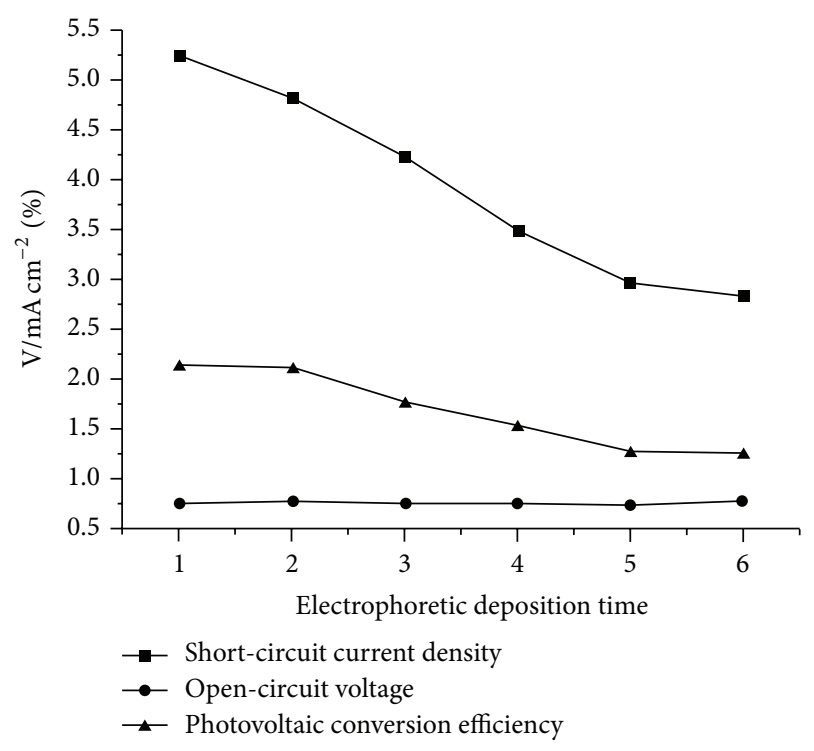

Figure 5: The effect of electrophoretic deposition times on properties of DSSC.

effectively enhance the absorption amount of dye and the photoelectric conversion efficiency can be further enhanced $[25,26]$. The nanotube structure fabricated by anodizing method is best arrayed, simple, and easy for fabrication and has low equipment cost. Through parameters, the fabricated nanoporous structure can be adjusted to achieve neatly arrayed nanoporous structure with pores in appropriate size. The photovoltaic conversion efficiency (2.96\%) of DSSC thickness $10.6 \mu \mathrm{m}$ was higher than the DSSC $(2.60 \%)$ thickness $10.0 \mu \mathrm{m}$ in [3]. The electrical field intensity during the deposited $\mathrm{TiO}_{2}$ films caused nonuniform film, so it has lower absorption amount of dye and the photovoltaic conversion efficiency.

For the same structure of photoelectrode [14, 15], the thickness of $\mathrm{TiO}_{2}$ film could be observed as an important relationship between short current density and photovoltaic conversion efficiency. If the thickness was $6.0 \mu \mathrm{m}$, the TNTTNP mixed structure of photoelectrode had performance higher than TNT or TNP, because the TNT-TNP mixed structure had enlarged specific surface area at the same active area with better current density and photovoltaic conversion efficiency of DSSC.

From Figure 5, the $J_{\mathrm{sc}}$ and $\eta$ were decreased with increasing electrophoretic deposition times. But, the $V_{\text {oc }}$ was not significantly change with increasing electrophoretic deposition times. The results explained that effect of electrophoretic deposition times on photovoltaic properties was dramatic, which resulted from suspension concentration which was changed, compared with initial suspension concentration, which led to nonuniform $\mathrm{TiO}_{2}$ charge quantity in $\mathrm{TiO}_{2}$ suspension in repeated process of electrophoretic deposition.

3.3. Analysis of the Electrochemical Impedance Spectroscopy. Electrochemical impedance spectroscopy (EIS) is an electrochemical measurement method which inputs sinusoidal 
TABLE 2: The comparison of DSSCs parameters with other references [3, 13-15].

\begin{tabular}{|c|c|c|c|c|c|c|}
\hline Sample structure & Thickness $(\mu \mathrm{m})$ & $V_{\mathrm{oc}}(\mathrm{V})$ & $J_{\mathrm{sc}}\left(\mathrm{mA} / \mathrm{cm}^{2}\right)$ & F.F. (\%) & $\eta(\%)$ & Reference \\
\hline TNP & 6.6 & 0.80 & 5.17 & 55.5 & 2.30 & \\
\hline TNP & 7.5 & 0.71 & 4.31 & 62.0 & 1.89 & \\
\hline TNP & 7.9 & 0.72 & 3.30 & 62.1 & 1.49 & \\
\hline TNP & 9.0 & 0.77 & 6.09 & 58.9 & 2.76 & In this study \\
\hline TNP & 10.6 & 0.77 & 7.20 & 53.4 & 2.96 & \\
\hline TNP & 12.9 & 0.74 & 4.44 & 46.8 & 1.55 & \\
\hline TNP & 15.9 & 0.75 & 6.31 & 53.4 & 2.54 & \\
\hline TNP & 10.0 & 0.69 & 5.70 & 66.00 & 2.60 & {$[3]$} \\
\hline TNT & 22.0 & 0.70 & 13.90 & 47.7 & 5.43 & [13] \\
\hline TNT-TNP & 6.0 & 0.75 & 11.50 & 53.3 & 4.89 & [13] \\
\hline TNT-TNP & 15.5 & 0.75 & 19.50 & 49.6 & 7.40 & [13] \\
\hline TNP & 1.5 & 0.30 & 0.49 & 50.0 & 0.07 & {$[14]$} \\
\hline TNP & 4.2 & 2.20 & 0.74 & 53.0 & 0.87 & {$[14]$} \\
\hline TNP & 6.0 & 0.75 & 7.95 & 74.0 & 4.37 & [15] \\
\hline
\end{tabular}

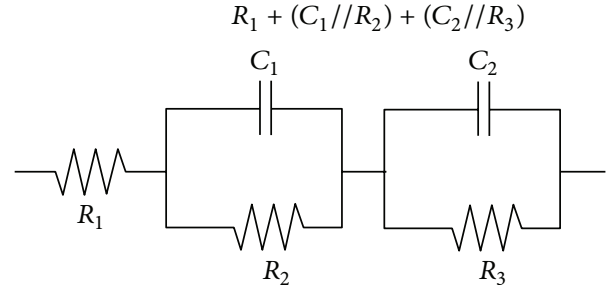

FIGURE 6: The equivalent circuit model of DSSC.

wave alternating current and the equivalent circuit model. The equivalent circuit model can describe the junction impedance, and the EIS measurement system can compute the value of junction impedance by Ohm's law. In the electrochemical system, the dye-sensitized solar cell consists of the anode electrode, the cathode electrode, and the electrolyte. Figure 6 showed the equivalent circuit model in the study. Table 3 described the physical meaning of each symbol in equivalent circuit model. Figure 7 showed the Nyquist plots of DSSCs which were prepared with different $\mathrm{I}_{2}$ dosages. The Nyquist plots were formed by real part impedance $(\operatorname{Re}(Z) / \mathrm{Ohm})$ and imaginary impedance $(-\operatorname{Im}(Z) / \mathrm{Ohm})$. And Table 4 showed the resistance and capacitance values which were measured by EIS. The experimental results showed increasing $R_{3}$ value with increasing $\mathrm{I}_{2}$ dosage. The larger $R_{3}$ value led to the fact that the electrons were more difficult to transmit at $\mathrm{TiO}_{2} /$ dye and electrolyte interface. However, the amount of absorbed dye increased with increasing the $\mathrm{TiO}_{2}$ thickness [26]. And the photovoltaic conversion efficiency had been improved.

\section{Conclusions}

Nanocrystalline $\mathrm{TiO}_{2}$ films were deposited on FTO substrates by the electrophoretic deposition method. The film thickness and crevices numbers of $\mathrm{TiO}_{2}$ film were increased with the deposition electric field intensity. And the thickness of

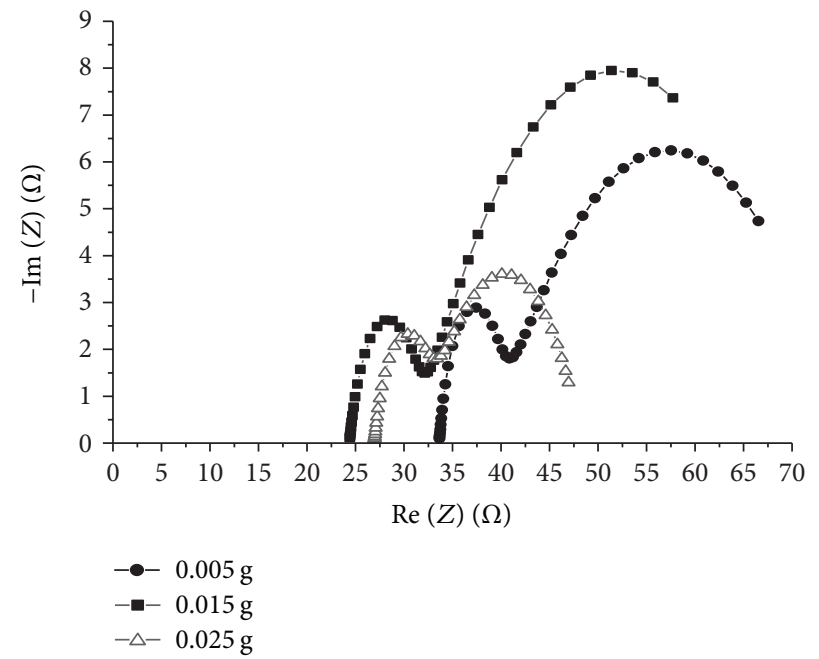

FIGURE 7: The Nyquist plots of DSSCs prepared with different $I_{2}$ dosages.

TABLE 3: The physical meaning of resistances and capacitances symbols.

\begin{tabular}{lc}
\hline Symbol & Physical meaning \\
\hline$R_{1}$ & Serial resistance of FTO glass/wire. \\
$C_{1} / / R_{2}$ & Impedance at $\mathrm{Pt} /$ electrolyte interface. \\
$C_{2} / / R_{3}$ & Impedance at $\mathrm{TiO}_{2} /$ dye/electrolyte interface. \\
\hline
\end{tabular}

$\mathrm{TiO}_{2}$ film increased with increasing deposition time and $\mathrm{I}_{2}$ dosage. By controlling the $\mathrm{I}_{2}$ dosages which could increase the surface electric charge of $\mathrm{TiO}_{2}$ particles, so the photovoltaic efficiency of DSSC was improved. The amount of absorbed dye was found to increase $\mathrm{TiO}_{2}$ thickness so as to improve the photovoltaic conversion efficiency of DSSC. However, the thicker $\mathrm{TiO}_{2}$ films could obtain the larger impedance at $\mathrm{TiO}_{2}$ layer. The experimental results showed that the $\mathrm{TiO}_{2}$ film deposited for $60 \mathrm{sec}$ which had the optimal $\mathrm{TiO}_{2}$ 
TABLE 4: The resistances and capacitances values of $\mathrm{TiO}_{2}$ films prepared at $60 \mathrm{sec}$ with different $\mathrm{I}_{2}$ dosages.

\begin{tabular}{lccccc}
\hline I $_{2}$ dosage $(\mathrm{g})$ & $R_{1}(\Omega)$ & $C_{1}(\mathrm{mF})$ & $R_{2}(\Omega)$ & $C_{2}(\mathrm{mF})$ & 0.018 \\
0.005 & 33 & 16.00 & 35 & 0.062 & 6 \\
0.015 & 24 & 25.00 & 41 & 8 & 0.530 \\
0.025 & 27 & 1.67 & 8 & 17 \\
\hline
\end{tabular}

film thickness of $10.6 \mu \mathrm{m}$, the open-circuit voltage $\left(V_{\mathrm{oc}}\right)$ was $0.77 \mathrm{~V}$, short-circuit current density $\left(J_{\mathrm{sc}}\right)$ was $7.20 \mathrm{~mA} / \mathrm{cm}^{2}$, fill factor (F.F.) was $53.41 \%$, and photovoltaic conversion efficiency $(\eta)$ was $2.96 \%$.

\section{Conflict of Interests}

The authors declare that there is no conflict of interests regarding the publication of this paper.

\section{Acknowledgment}

This study has been supported by National Science Council, Taiwan, under the Contracts NSC 102-2221-E-224-075 and MOST 103-2221-E-224-073.

\section{References}

[1] B. O'Regan and M. Graetzel, "Low-cost, high-efficiency solar cell based on dye-sensitized colloidal $\mathrm{TiO}_{2}$ films," Nature, vol. 353, no. 6346, pp. 737-740, 1991.

[2] N. J. Smith, K. J. Emmett, and S. J. Rosenthal, "Photovoltaic cells fabricated by electrophoretic deposition of CdSe nanocrystals," Applied Physics Letters, vol. 93, no. 4, Article ID 043504, 2008.

[3] W. Jarernboon, S. Pimanpang, S. Maensiri, E. Swatsitang, and V. Amornkitbamrung, "Optimization of titanium dioxide film prepared by electrophoretic deposition for dye-sensitized solar cell application," Thin Solid Films, vol. 517, no. 16, pp. 4663-4667, 2009.

[4] J.-A. Jeong and H.-K. Kim, "Thickness effect of RF sputtered $\mathrm{TiO}_{2}$ passivating layer on the performance of dye-sensitized solar cells," Solar Energy Materials \& Solar Cells, vol. 95, no. 1, pp. 344-348, 2011.

[5] C.-M. Lin, Y.-C. Chang, J. Yao, C. Wang, C. Luo, and S. Yin, "Multi-step hydrothermally synthesized $\mathrm{TiO}_{2}$ nanoforests and its application to dye-sensitized solar cells," Materials Chemistry and Physics, vol. 135, no. 2-3, pp. 723-727, 2012.

[6] A. I. Kontos, A. G. Kontos, D. S. Tsoukleris, M.-C. Bernard, N. Spyrellis, and P. Falaras, "Nanostructured $\mathrm{TiO}_{2}$ films for DSSCS prepared by combining doctor-blade and sol-gel techniques," Journal of Materials Processing Technology, vol. 196, no. 1-3, pp. 243-248, 2008.

[7] W. A. Daoud and M. L. Turner, "Effect of interfacial properties and film thickness on device performance of bilayer $\mathrm{TiO}_{2}$ poly(1,4-phenylenevinylene) solar cells prepared by spin coating," Reactive and Functional Polymers, vol. 66, no. 1, pp. 13-20, 2006.

[8] H. Zhu, J. Yang, S. Feng, M. Liu, J. Zhang, and G. Li, "Growth of $\mathrm{TiO}_{2}$ nanosheet-array thin films by quick chemical bath deposition for dye-sensitized solar cells," Applied Physics A, vol. 105, no. 3, pp. 769-774, 2011.
[9] A. Chávez-Valdez, M. Herrmann, and A. R. Boccaccini, "Alternating current electrophoretic deposition (EPD) of $\mathrm{TiO}_{2}$ nanoparticles in aqueous suspensions," Journal of Colloid and Interface Science, vol. 375, no. 1, pp. 102-105, 2012.

[10] J.-E. Hu, S.-Y. Yang, J.-C. Chou, and P.-H. Shih, "Fabrication of flexible dye-sensitised solar cells with titanium dioxide thin films based on screen-printing technique," Micro and Nano Letters, vol. 7, no. 12, pp. 1162-1165, 2012.

[11] H. Chang, T. L. Chen, K. D. Huang, S. H. Chien, and K. C. Hung, "Fabrication of highly efficient flexible dye-sensitized solar cells," Journal of Alloys and Compounds, vol. 504, supplement 1, pp. S435-S438, 2010.

[12] I. Corni, M. P. Ryan, and A. R. Boccaccini, "Electrophoretic deposition: from traditional ceramics to nanotechnology," Journal of the European Ceramic Society, vol. 28, no. 7, pp. 1353-1367, 2008.

[13] H. Chang, C.-H. Chen, M.-J. Kao, S.-H. Chien, and C.-Y. Chou, "Photoelectrode thin film of dye-sensitized solar cell fabricated by anodizing method and spin coating and electrochemical impedance properties of DSSC," Applied Surface Science, vol. 275, pp. 252-257, 2013.

[14] M. Hamadanian, A. Gravand, and V. Jabbari, "High performance dye-sensitized solar cells (DSSCs) achieved via electrophoretic technique by optimizing of photoelectrode properties," Materials Science in Semiconductor Processing, vol. 16, no. 5, pp. 1352-1359, 2013.

[15] I. Shin, H. Seo, M.-K. Son, J.-K. Kim, K. Prabakar, and H.-J. $\mathrm{Kim}$, "Analysis of $\mathrm{TiO}_{2}$ thickness effect on characteristic of a dye-sensitized solar cell by using electrochemical impedance spectroscopy," Current Applied Physics, vol. 10, no. 3, pp. S422S424, 2010.

[16] A. R. Gardeshzadeh, B. Raissi, and E. Marzbanrad, "Electrophoretic deposition of $\mathrm{SnO}_{2}$ nanoparticles using low frequency AC electric fields," Materials Letters, vol. 62, no. 10-11, pp. 1697-1699, 2008.

[17] L. Besra and M. Liu, "A review on fundamentals and applications of electrophoretic deposition (EPD)," Progress in Materials Science, vol. 52, no. 1, pp. 1-61, 2007.

[18] H. Morgan and N. G. Green, AC Electrokinetics: Colloids and Nanoparticles, Research Studies Press, 1st edition, 2002.

[19] P. Sarkar and P. S. Nicholson, "Electrophoretic deposition (EPD): mechanisms, kinetics, and application to ceramics," Journal of the American Ceramic Society, vol. 79, no. 8, pp. 19872002, 1996.

[20] E. V. Shevchenko, D. V. Talapin, N. A. Kotov, S. O’Brien, and C. B. Murray, "Structural diversity in binary nanoparticle superlattices," Nature, vol. 439, no. 7072, pp. 55-59, 2006.

[21] J. Zhang, S. Li, H. Ding et al., "Transfer and assembly of large area $\mathrm{TiO}_{2}$ nanotube arrays onto conductive glass for dye sensitized solar cells," Journal of Power Sources, vol. 247, pp. 807812,2014 
[22] B.-X. Lei, J.-Y. Liao, R. Zhang, J. Wang, C.-Y. Su, and D.-B. Kuang, "Ordered crystalline $\mathrm{tio}_{2}$ nanotube arrays on transparent FTO glass for efficient dye-sensitized solar cells," Journal of Physical Chemistry C, vol. 114, no. 35, pp. 15228-15233, 2010.

[23] T. Y. Lee, P. S. Alegaonkar, and J.-B. Yoo, "Fabrication of dye sensitized solar cell using $\mathrm{TiO}_{2}$ coated carbon nanotubes," Thin Solid Films, vol. 515, no. 12, pp. 5131-5135, 2007.

[24] C. Randall and J. V. Tassel, "Electrophoretic deposition," in Encyclopedia of Materials: Science and Technology, pp. 27332738, Bernhard Ilschner, 2001.

[25] B. Tan and Y. Wu, "Dye-sensitized solar cells based on anatase $\mathrm{TiO}_{2}$ nanoparticle/nanowire composites," Journal of Physical Chemistry B, vol. 110, no. 32, pp. 15932-15938, 2006.

[26] L. Zhao, J. Yu, J. Fan, P. Zhai, and S. Wang, "Dye-sensitized solar cells based on ordered titanate nanotube films fabricated by electrophoretic deposition method," Electrochemistry Communications, vol. 11, no. 10, pp. 2052-2055, 2009. 



Submit your manuscripts at http://www.hindawi.com
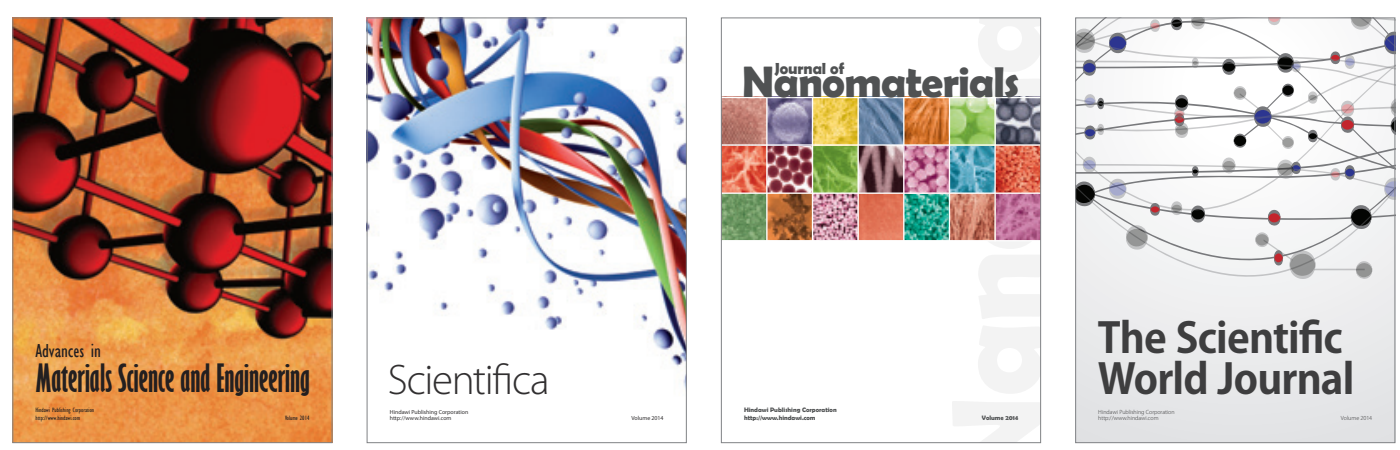

\section{The Scientific World Journal}
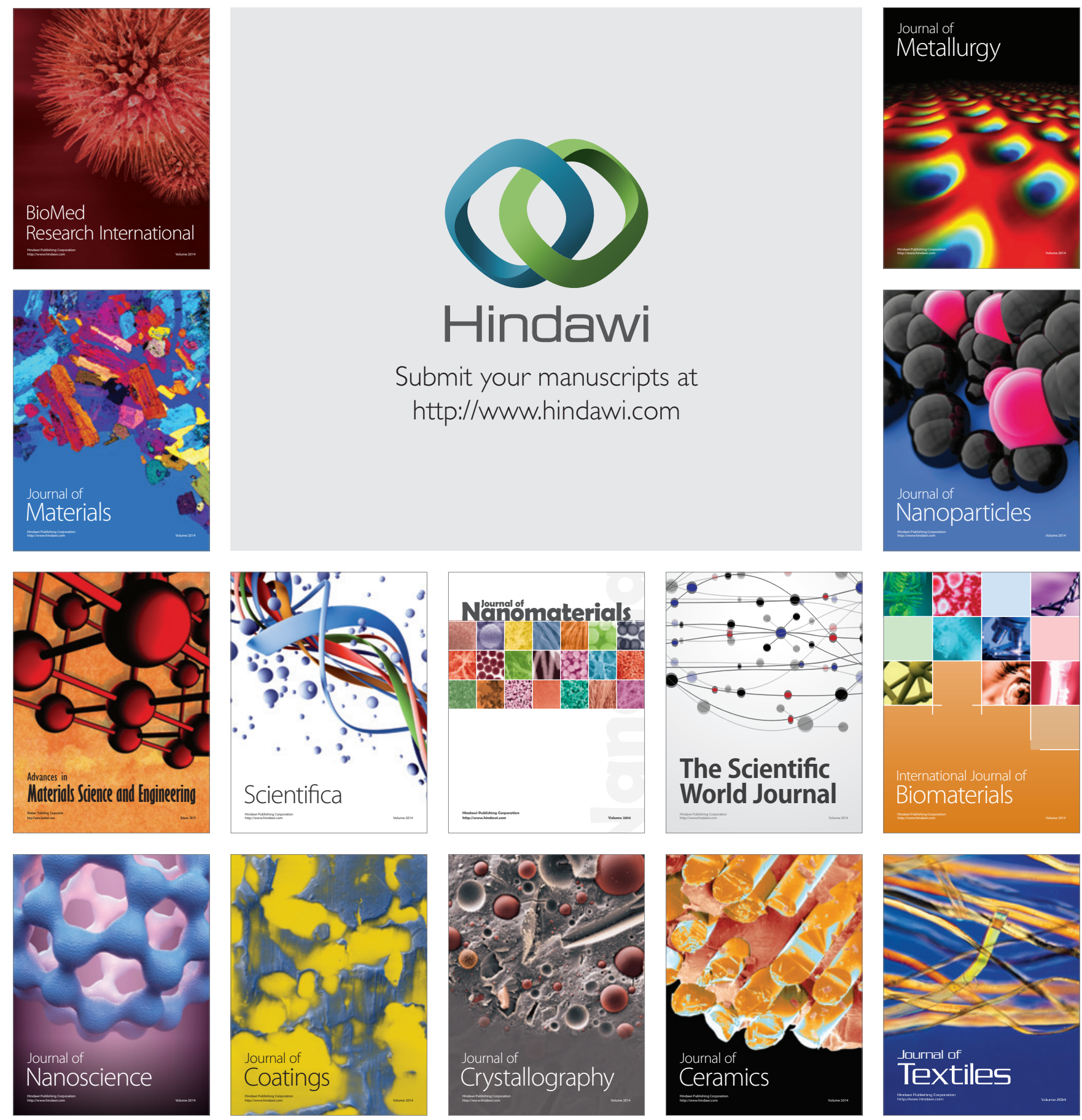